\title{
From Central Asia to South Africa: In Search of Inspiration in Rock Art Studies
}

\author{
ANDRZEJ ROZWADOWSKI \\ Adam Mickiewicz University \\ Instytut Wschodni \\ Wydział Historyczny \\ Uniwersytet im. Adama Mickiewicza \\ ul. Umultowska 89D \\ 61-614 Poznań, Poland \\ rozw@amu.edu.pl
}

\begin{abstract}
The paper describes the story of discovering South African rock art as an inspiration for research in completely different part of the globe, namely in Central Asia and Siberia. It refers to those aspect of African research which proved to importantly develop the understanding of rock art in Asia. Several aspects are addressed. First, it points to importance of rethinking of relationship between art, myth and ethnography, which in South Africa additionally resulted in reconsidering the ontology of rock images and the very idea of reading of rock art. From the latter viewpoint particularly inspiring appeared the idea of three-dimensionality of rock art 'text'. The second issue of South African 'origin,' which notably inspired research all over the world, concerns a new theorizing of shamanism. The paper then discusses how and to what extent this new theory add to the research on the rock art in Siberia and Central Asia.
\end{abstract}

Keywords: South Africa; Central Asia; rock art; interpretation

When in 1992 I was beginning the research on rock art in Uzbekistan, not only Central Asia, but especially the phenomenon of rock art appeared to be a challenge, which, as I soon realized, was difficult to face basing solely on traditional 
archaeological education. Every following field expedition was revealing new questions, which were forcing me to search for professional knowledge in the sphere of rock art research. Growing awareness of the need to go beyond the traditional archaeology to find methods relevant to study rock art was the very impetus that led me to discover South African rock art. This discovery quickly proved to be extremely productive and inspired my research for many years. This article is a brief summary of my encounter with rock art of South Africa. I will outline these aspects of South African rock art research, which became inspiration for my Asian studies, and later also led to develop another project on rock art in Tanzania.

\section{Paths to South Africa}

My first meeting with the rock art of South Africa took place in Europe. As part of the search for professional knowledge, in 1996 I got a scholarship to attend the course "Archaeology and Anthropology of Rock Art," which was taught at the University of Southampton in Great Britain by Thomas Dowson, a respected rock art researcher from South Africa, with already recognized achievements. Actually, the course dealt with many theoretical questions, which were discussed through references to rock art from all over the world. Due to the fact, however, that the teacher came from South Africa, rock art of this part of the world naturally was most comprehensively presented. Thomas Dowson was also previous deputy director of the Rock Art Research Institute (RARI) at the Witwatersrand University in Johannesburg - then the first such rock art institute in the world. It was therefore not only my first, but by all means also the most competent meeting with African rock art.

Shortly thereafter, I delivered a speech at the conference "Theoretical Perspectives in Rock Art Research" (published three years later - Rozwadowski 2001a), which took place in 1998 in Alta, Norway. There I also met for the first time James David Lewis-Williams, the founder of RARI and the undisputed leader of a new school of rock art research. The meeting was attended also by Benjamin Smith the new director of the Institute (it was then that Lewis-Williams retired). After my speech, David Lewis-Williams came to me on the sidelines and said, "you have to come to South Africa." This was the idea which just needed to be embraced. It was like the wind in the sails, which only had to be developed. Then, in 2001, thanks to the support of the Stefan Batory Foundation, I came to Johannesburg. Three months of my stay at RARI was therefore the culmination of my search for inspiration in rock art research and the second, this time a direct meeting with the South African rock art. Together with researchers from RARI I visited many locations of rock paintings, mainly in the Drakensberg Mountains. 
This resulted in creating a photographic collection of unique samples of San rock art, containing about 1,000 photographs. Another valuable aspect of studies was gaining a better theoretical knowledge of rock art interpretation. In this respect the Johannesburg research school enjoyed international acclaim. In the following part of the paper I will turn attention to those aspects of this research which made the South African studies famous throughout the world, and which importantly inspired also my research on Asian rock art.

\section{Rock art of South Africa}

Rock Art of South Africa includes several art traditions: the rock art of San/Bushmen foragers, herder rock art of Khoekhoen, and the rock art of Bantu-speaking farmers (Lewis-Williams 1983b; Deacon 1999; Smith and Ouzman 2004; Smith 2006, 2013). The oldest one is the Bushmen (or San) rock art, which prevails in the south of the Zambezi river and the Angolan border with Namibia. Thanks to extremely rich documentation of Bushmen beliefs and their language, done in the nineteenth century by the German linguist Wilhelm Bleek, and later on continued by his family members (his sister-in-law Lucy Lloyd and then by his daughter Dorothea Bleek) (e.g. Lewis-Williams 2000b), it is also the best known (i.e. understood) African rock art tradition, also when it comes to the hunting-gathering rock art traditions in the world (Lewis-Williams 1985). As its last creators lived in the nineteenth century, researchers deal with unique and very informative first-person eyewitness accounts (Lewis-Williams 1986). A large part of Bushman rock art, i.e. that which is preserved, was most likely created in the last two thousand or hundreds of years, although its history is certainly much older. This is evidenced by archaeological excavations, in which fragments of rocks with paintings or engravings were discovered. Some researchers suggest that the oldest example of this tradition are the paintings discovered on a rock slab in the cave of Apollo 11, which are dated to 27,000 years (Lewis-Williams 1984). Since so far no similar findings from so early times are known, taking the Apollo 11 piece of art as the indicator of the beginning of the Bushmen tradition of making images on rocks should be treated with caution. There are, however, more findings from more 'recent' times, which suggests that history of Bushmen tradition of producing rock art is as old as 10,000 years: different pieces of rock paintings from the Wonderwerk cave were dated to 10,000, 5,200 and 4,000 years, in the Boomplaas cave there are discoveries of paintings estimated to be 6,400 and 2,000 years old, in a cave at the mouth of the Klasies river other findings were dated to 4,100 and 2,300 years, and in the Collingham cave to 1,800 years (Lewis-Williams 2000a). 
Studies on the South African rock art, which have been developed in RARI, proved to be a breakthrough for both Africa and the world. On the one hand, they reaffirmed the Africanness of this ancient art (for a long time it was thought that the Bushmen were too primitive to create paintings on rocks), on the other hand, Lewis-Williams's thoughts on how to interpret Bushmen rock art became an important breakthrough in the theory of interpretation of rock art on a global scale. This is all the more fascinating when we realize that till 70s of the twentieth century the study of rock art in Africa was regarded as an amateur field of research (Mguni 2012: 99). The case of South Africa is therefore a good exemplification of the fact that progress in any field of knowledge is primarily theoretical, that it is a new reflection on how to approach a problem that determines new discoveries.

\section{Image, myth and ritual: 'reading' rock art}

Interpretation of rock art has always been a challenge for archaeologists. First theories, which were conceived at the end of the nineteenth and in the first half of the twentieth centuries and pertained to European cave art, quickly spread outside of Europe and became paradigms for interpreting any piece of prehistoric art in any part of the world. It was the theory of 'art for the art's sake' and a little later even more profound hypotheses according to which rock art was a form of hunting magic or magic of fertility (Ucko and Rosenfeld 1967; Clottes 2016). The latter hypotheses, especially of hunting magic, were strongly shaped by the conviction that rock art played an active role in social contexts aiming at maintaining existence - producing images on rocks was assumed to result from a daily struggle for food which forced people to practice magic rituals to ensure a successful hunt. These interpretations were also based on selective ethnographic analogies, e.g. from North American Indians or Australian Aborigines. Interestingly, interpretations of prehistoric rock art through the prism of analogies drawn from cultures distant in time and space soon started to arouse controversies. When the power of evolutionary thinking in the study of culture began to wane, researchers began to notice shortcomings of the ideas according to which rock art of any place on earth could be explained by one universal idea. The problem was that archaeologists lacked well-documented ethnographic contexts of producing rock art, which could shed more light on the issue of potential motivations and meanings of rock art. South Africa turned out to be a real breakthrough in this regard.

The critical point was the turn to ethnohistory. In South Africa it was fully possible thanks to the great effort of the previously mentioned Wilhelm Bleek 
(and his family members who documented a huge number of Busmen beliefs) as well as to some accidental observations - most significant appeared those made by Joseph Millerd Orpen, who happened to be informed by a San man named Quing about the meaning of rock paintings accidently discovered by Orpen in 1873 in Lesotho (Orpen 1874; McGranaghan, Challis and Lewis-Williams 2013). These data were used in crucial works by Patricia Vinnicombe and David Lewis-Williams. After more than a decade since their first journal papers, their two monumental monographs were published: People of the Eland: Rock Paintings of the Drakensberg Bushmen as a Reflection of Their Life and Thought (Vinnicombe 1976) and Believing and Seeing: Symbolic Meanings in Southern San Rock Paintings (Lewis-Williams 1981a). Both works shared two common features: first, they moved away from global European theories and European aesthetics, second, they focused on possibilities of getting insight into the symbolic realm of rock art through the lens of local cultural tradition. In terms of content, this meant a turn to the ethnography of the Bushmen, and from the methodological perspective - a turn to anthropological theories of symbolism of human actions.

Here, a comment has to be made on the global discourse of interpretation of rock art in the mid-twentieth century. During this time, structuralist and semiotic analyses begun to boldly penetrate minds of researchers. They were believed to be a scientific remedy for the dubious manipulation of ethnographic analogies. If ethnographic analogies are suspicious methodologically, structuralists would say, any search for meaning in prehistoric rock art should be abandoned as unscientific. If, however, to accept that human activities are oriented to communicate something (so are purposeful), the communication process is governed by specific rules. What a researcher could postulate, therefore, was an attempt to discover (define) the structure(s) and rules of the graphic codes in rock art. The repeatability of relationships between rock art motifs (syntax) could be the key to the assertion that given art is structured by a specific code (Leroi-Gourhan's studies of European cave art were most spectacular and influential in this regard, e.g. Leroi-Gourhan 1968).

This turn towards the structures instead of singular images had other consequences - semantic studies reached an impasse. Interpretations based on ethnography were criticized as suspicious and unscientific. The first structuralist studies in South Africa were also conducted in this climate (Vinnicombe 1967; Lewis-Williams 1972, 1974). But the ambition to reveal the semantic sphere of images turned out to be stronger than structuralists' warnings of methodological risks involved in research on prehistoric semantics. And in this regard the South African studies have become particularly significant because they led to overcome the deadlock associated with the lack of faith in the value of the study of rock art from the perspective of hidden meanings. The postulate of Lewis- 
-Williams (1972: 64) that the study of rock art must move from syntactic to semantic analyses became an inspiration not only for researchers in Africa, but entailed a wave of similar studies in other parts of the world. The South African research school reoriented the aim of rock art study: the goal of studying rock art is its meaning - "comprehension of what the images meant (semantically, affectively, socially and politically) to the people who made them and originally viewed them" (Lewis-Williams 2001b: 24).

As a result, a new model of 'reading' rock art was developed. From the African perspective the model concerned the skill to recognize links between the two categories of sources - in this case: the rock art and ethnographically documented beliefs (Lewis-Williams 1983a, 2006; Lewis-Williams and Loubser 1986). To put it in terms of semiotics it can be expressed in the question: how does the text of art link with the text of myth or ritual? Is art a graphic illustration of myths / beliefs / rituals? The South African school demonstrates that the case is not so obvious. It shows that the key to the 'translation' is in links between these different (from our perspective) spheres of culture. These links Lewis-Williams defined as metaphors that transcend both art and myth or ritual. Reading of art implies thus the ability to recognize these links, in this case - metaphors.

This perspective has become an important inspiration for my own 'reading' rock art in Central Asia, where I approached to some extent a similar question - namely of the interrelation between petroglyphs and mythology. In my case it concerned myths of the so-called Indo-Iranians, ancient Aryan peoples who lived in Central Asia about four thousand years ago, who moved later on to India to give backgrounds for historical Hinduism. The main research question therefore was methodological: how to compare myths and rock art, or how to identify the myths in iconography of rock art? The South African idea that both art and myth (or mythology) need to be interpreted actually was a great stimulus for my reading of the petroglyphs in Uzbekistan and Kazakhstan (Rozwadowski 2001a, 2001b, 2001c, 2003, 2004). This fresh perspective indeed enabled me to reveal many previously unnoticed aspects of the correspondences between Central Asian rock art and the Indo-Iranian myths. This also allowed me to figure out images, which previously had not been considered to be linked with the tradition of the Indo-Iranian peoples.

Theoretical reflection on interpretation of rock art, developed in South Africa, revealed one more important aspect related to the idea of 'reading' rock art. It concerns the relationship between images and the rock itself. Careful analysis of rock paintings or engravings in situ showed that some of them are somehow associated with the cracks, crevices and other facets of the rock face, giving an impression of emerging from or disappearing into cracks or clefts in the rock 
(Lewis-Williams 1981b, Lewis-Williams and Dowson 1990; Lewis-Williams et al. 2000; Dowson 1998; Hollmann 2005; Morris 2010; Hampson 2013). The very rock was then most probably an integral part of the 'image' for the original artists. If so, reading of rock art should not be focused solely on images (as seen in books in the form of black and white drawings presented on a white page) - 'reading' should involve much more aspects of the image, like how and where it was done. The meaning results then not only from the depiction but can significantly be shaped by the relation of the image to the rock face: image and rock are interconnected - not only physically but also symbolically. Farther research on rock art and San beliefs led South African researchers to hypothesize that rock face was a kind of curtain beyond which another world could be encountered. Rock face was then like a membrane which San ritual practitioners penetrated and the images on rocks expressed this metaphysical experience.

This conclusion stimulated also researchers in other parts of the world to re-examine rock art in their research areas from this fresh perspective. Soon it appeared that similar phenomena can be observed in America or Europe (both in Palaeolithic caves as well as in Post-Palaeolithic rock art). I found such images also in Central Asia (Rozwadowski 2001c, 2002a, 2002b, 2003), and later on in Siberia (Rozwadowski 2017a, 2017b). It is worth noting that such interrelationships have been often discovered at already well-known sites. It demonstrates that the perception of certain aspects of rock art is not only conditioned by the accuracy of looking at and documenting them, but is seriously theory-driven. It was also the case in Central Asia and Siberia, where I discovered this phenomenon in relation to rock art sites already known for decades.

Referring to the theoretical consideration of reading rock art, South African researchers demonstrate that rock art is neither literal nor two-dimensional. And this point of departure is today widely accepted and further explored (Rozwadowski 2017b).

\section{Shamanism: phenomenon and history}

South African rock art turned out to be inspiring for yet another reason. Namely, research on the ritual sphere of the Bushmen has shown that an important part of South African rock art was intimately bound up with curing dance, the most significant religious ritual of the San (Lewis-Williams 1980, 1981a, 1983a, 1983b, 1987b, 1992, 2003; Lewis-Williams and Dowson 1989; Lewis-Williams and Challis 2011). This ritual involved whole local community, but the key role played a medicine man or a shaman, who achieving a state of trance got into the possession of supernatural potency $n / u m$, required to cure a sick person. Trance 
was commonly experienced by Bushmen shamans, and rock art in South Africa is rich in depictions of humans in trance (which can be identified in rock art through graphic representations of sensations felt by individuals in the state of trance). This is why South African rock art has been labelled as shamanistic or shamanic. This aspect of South African rock art appeared equally interesting from the point of view of my Asian research as in the beginning of the $21^{\text {st }}$ century my research interest has moved from proper Central Asia to Siberia, so called terra mater of shamanism.

The fact that Bushmen rock art was intimately bound up with trance dance encouraged researchers to investigate the question what happens with a person while in trance and how trance experience could influence production of images on rocks. Could the trance visions of the other world be expressed graphically? And how? To answer these questions researchers started exploring phenomenon of altered states of consciousness to check what people feel and see while in trance. Results were intriguing. Neuropsychological research has proved that people who enter trance experience similar somatic, aural and visual hallucinations, which are in part universal and, as ethnological studies added, may account for much of the imagery found in art inspired by visionary experiences. Studies of Bushmen rock art therefore provided a basis for a new theory of interpreting rock art which soon developed into a wider theoretical proposal popularly known as 'neuropsychological model' (Lewis-Williams and Dowson 1988 - the model in fact was focused on Upper Palaeolithic cave art of Western Europe, which according to this approach was claimed to be shamanic, i.e. that it was created in contexts which involved trance experiences, see e.g. Lewis-Williams 1997a, 1997b, 2002; Clottes and Lewis-Williams 1998). One of the most interesting (and on the other hand equally hotly debated) aspects of this research was a discovery that visual hallucinations include so-called entoptic phenomena - geometric patterns created by brain and then visualized within the optic system ('entoptic' means within the optic system), and that such patterns can also be found in rock art. Discovery of such images in rock art was then only a farther proof that Bushmen rock art was inspired by trance experience. It also proved that rock art is not a straightforward record of the real world (e.g. Lewis-Williams 1988a, 1988b, 1995, 2001a, 2003; Lewis-Williams and Challis 2011). The questions which kept nagging me were: how can this theory be helpful for interpreting Asian art? To what extent can the model of identification of shamanic nature of rock art developed in Africa be helpful in analyzing shamanic art in Central Asia and Siberia? Can it help to discover new aspects of shamanic rock art in Asia?

Application of the African observations to rock art in Siberia and Central Asia has shown that images of potentially visionary nature can indeed be detected in 
this art (Rozwadowski 2001c, 2003, 2012a, 2012b, 2017a, 2017b). What was surprising however was that such images, including entoptics, appear to be very limited in number (Rozwadowski 2017a). One could conclude from this that shamanism was not a frequent context of producing rock art in Asia. But maybe visionary states were not favoured by Asian people to depict them in rock art, or Asian shamanic practices randomly involved trance experiences. Furthermore, this is interesting as we definitely know that some part of rock art in Siberia was related to shamanism - clear images of shamans on rocks are a proof of it (Rozwadowski 2015, 2017a) (the chronology of this shamanic art in Asia is to some extent of lesser importance for discussing this issue). From the perspective of the history of Asian cultures a further dilemma appeared. Namely, in the history of Central Asia at least one more cultural context, next to shamanism, can be indicated, in which ritual trance states were practised. This is the culture of the previously mentioned Indo-Iranians: ancient Aryans, who 4,000 years ago mastered rituals which involved ingestion of the hallucinogenic drink: soma. Trance-induced art in Central Asia dated to this ancient time could be then related to Indo-Iranian heritage. Identification of trance-inspired images in prehistoric rock art in Central Asia can then be a suggestion that the images were produced within a culture, in which trance rituals were practised. Should however such a 'visionary culture' be automatically labelled as shamanic? The problem is that shamanism in Asia has one additional face. Namely, in Siberia shamanism is 'something' more than merely an anthropological term to define a type of culture (like animistic, totemic etc.). Instead, shamanism in Siberia functions as an indigenous religion, which has turned out to be even more important after the collapse of the Soviet Union - since then shamanism has become in Siberia a source of cultural, and in some cases also of national identity (Rozwadowski 2012a).

The confrontation of Asian and African research experiences finally made me realize a very simple (though important) truth that shamanism in rock art studies has many faces and cannot be understood identically in every context. This is why I proposed to distinguish between two concepts of shamanism, which are used in archaeological discourse. This is significant as applications of shamanism in archaeology, and particularly in rock art studies, have caused a lot of controversies, often very emotionally expressed. I suggested then (Rozwadowski 2009, 2012a, 2012b) to distinguish between Siberian shamanism and the 'typological' shamanism, which is widely employed in research. While the former can in my opinion be termed historical (not necessarily classical) shamanism, the latter may be defined as phenomenological. Possibly even more neutral term could be 'archaeology of altered states of consciousness' instead of 'archaeology of shamanism.' 


\section{From South Africa to Tanzania}

In 2014 the Polish involvement in the study of South African rock art gained new impetus. Young student Maciej Grzelczyk was awarded a so-called Diamond Grant (for outstanding students to conduct their own research) to investigate rock art of the Kondoa region in central Tanzania, and I was assigned as a supervisor of this research. Tanzania, of course, belongs to Eastern Africa, but its rock art appears to share some common features with Bushmen rock paintings of south of the continent. South African rock art became thus once more the inspiration for new research.

The main topic of this project is ethno-archaeological analysis of rock paintings at the Kondoa region in central Tanzania. This rock art is unique as this is the only kind of rock art outside of South Africa which can be related to the Bushmen tradition. This hypothesis is based first of all on cultural affinities between the Sandawe and the Hadza of Tanzania and the Bushmen (San) of South Africa. The Sandawe and the Hadza in fact speak languages which belong to the so-called click languages, i.e. languages with click consonants, which are used today only by the Khoisan peoples of Southern Africa, including the Bushmen. Historical reconstructions suggest however that in much older times the sphere of Khoisan culture was not limited to the south of the continent, but extended towards the north-east, to the 'Horn of Africa' (Culson and Campbell 2001: 24-29), and the Sandawe are possibly the most northern descendants of this tradition. Despite the language, correspondences between today so separated peoples include also symbolic and ritual aspects of their cultures. For example, the ritual dance of the Sandawe, known as simbó, during which people are 'transformed' into lions, evokes analogies with South African Bushmen curing dance, where medicine-men ('shamans') harness supernatural potency $n / u m$ believed to be hidden in a powerful animal, which in South Africa most commonly is associated with an eland antelope (Lewis-Williams 1987a). Rock paintings of the Kondoa in Tanzania are similar to South African rock art also iconographically: these are fine and detailed anthropomorphic and zoomorphic images, painted with thin lines, which significantly differ from rock imagery of surrounding area where geometric and more 'crude' patterns prevail. The latter belong to the tradition of pastoral Bantu. All this leads to the conclusion that the Kondoa rock art of present-day Tanzania probably originated within the culture of ancient foragers, who were ancestral not only to the today Sandawe, but also to the Bushmen of southern Africa (Smith 2006).

Previously mentioned theoretical advances in interpreting South African rock art, focused on the re-definition of the relationship between art, mythology 
and ritual, allow that the models of interpretation of rock art developed in southern Africa can be tested in relation to the paintings of Tanzania (Lewis-Williams 1986; Garlake 1995). It is therefore the key topic of the currently ongoing project (Grzelczyk 2015, 2016; Grzelczyk and Rozwadowski 2017).

\section{Closing remarks}

By virtue of the field and theoretical research achievements, briefly described in this paper, South African rock art is definitely one of the most interesting samples of rock art throughout the world. It attracts public attention not only because of its beauty, but equally by its symbolic complexity, which was realized when researchers moved away from the Eurocentric theories and began to explore it through the prism of Indigenous culture. It is worth noting that South Africa today offers many rock art sites open for tourists. Besides their research efforts, South African scholars were indeed very much engaged also in developing infrastructure to make this oldest artistic treasure of South Africa widely accessible (Laue, Turkington and Smith 2002; Smith and Duval 2012; Duval and Smith 2014; Morris 2014). Probably the best global sign of their achievements is the new coat of arms of the Republic of South Africa, where the past of the country is recalled through the motif of a pair of human figures derived from Bushmen rock art, accompanied by the motto in the extinct /Xam language !Ke e: xarra //ke ... (drafted by David Lewis-Williams) 'Unity in diversity,' or translating it literally 'Diverse people unite' (Smith et al. 2000: 468) or 'People who are different come / be together' (Bernard 2004: 16; Homrik 2001: 68).

\section{Bibliography}

Bernard, Alan J. 2004. “Coat of Arms and the Body Politic: Khoisan Imagery and South African National Identity." Ethnos 69(1): 5-22.

Clottes, Jean. 2016. What is Paleolithic Art? Cave Paintings and the Dawn of Human Creativity. Chicago \& London: University of Chicago Press.

Clottes, Jean, and J. David Lewis-Williams. 1998. The Shamans of Prehistory: Trance and Magic in the Painted Caves. NewYork: Harry N. Abrams.

Coulson, David, and Alec Campbell. 2001. African Rock Art: Paintings and Engravings on Stone. New York: Harry N. Abrams.

Deacon, Janet. 1999. "South African Rock Art." Evolutionary Anthropology 8: 48-64.

Dowson, Thomas A. 1998. "Rain in Bushman Belief, Politics and History: The Rock-art of Rain-Making in the South-Eastern Mountains, Southern Africa." The Archaeology of Rock-Art. Eds. C. Chippindale, and P.S.C. Taçon. Cambridge: Cambridge University Press. 73-89. 
Duval, Melanie, and Benjamin Smith. 2014. "Seeking Sustainable Rock Art Tourism: The Example of the Maloti-Drakensberg Park World Heritage Site." South African Archaeological Bulletin 69: 34-48.

Garlake, Peter. 1995. The Hunter's Vision: The Prehistoric Art of Zimbabwe. Seattle: University of Washington Press.

Grzelczyk, Maciej. 2015. "Rock Paintings from Poro Banguma I and Banguma I from the Usandawe Area (Kondoa District, Tanzania)." Bollettino del Centro Camuno di Studi Preistorici 39: 21-26.

2016. "State of Preservation of Rock Art Sites in Usandawe Area, Tanzania." Bollettino del Centro Camuno di Studi Preistorici 41: 138-142.

Grzelczyk, Maciej, and Andrzej Rozwadowski. 2017. "Sztuka naskalna regionu Kondoa w Tanzanii. Gdzie archeologia spotyka się z etnologią." Sztuka naskalna: polskie doświadczenia badawcze. Ed. A. Rozwadowski. Warszawa-Torun: Polski Instytut Studiów nad Sztuką Świata. 51-72.

Hampson, Jamie. 2013. “The Materiality of Rock Art and Quartz: A Case Study from Mpumalanga Province, South Africa." Cambridge Archaeological Journal 23(3): 363-372 .

Hollmann, Jeremy C. 2005. "'Swift-people': Therianthropes and Bird Symbolism in Hunter-Gatherer Rock-Paintings, Western and Eastern Cape Provinces, South Africa." South African Archaeological Society, Goodwin Series 9: 21-33.

Hromnik, Cyril A. 2001. "!Ke e: Ixarra ke - the Qena Motto in the South African Coat of Arms." Quarterly Bulletin of the National Library of South Africa 56(2): 65-72.

Laue, Ghilraen, Tara Turkington, and Benjamin Smith. 2002. "Presenting South African Rock Art to the World: Two Major New Public Rock Art Site Developments for 2002." The Digging Stick 18(3): 5-7.

Leroi-Gourhan, André. 1968. The Art of Prehistoric Man in Western Europe. London: Thames and Hudson.

Lewis-Williams, James David. 1972. "The Syntax and Function of the Giant's Castle Rock-Paintings." South African Archaeological Bulletin 27: 49-65.

1974. "Superpositioning in a Sample of Rock Paintings from the Barkly East District." South African Archaeological Bulletin 29: 93-103.

1980. "Ethnography and Iconography: Aspects of Southern San Thought and Art." Man 15: 467-482.

1981a. Believing and Seeing: Symbolic Meanings in Southern San Rock Paintings. London and San Francisco: Academic Press.

1981b. "The Thin Red Line: Southern San Notions and Rock Paintings of Supernatural Potency." South African Archaeological Bulletin 36: 5-13.

. 1983a. "Introductory essay: science and rock art." South African Archaeological Society, Goodwin Series 4: 3-13.

1983b. The Rock Art of Southern Africa. Cambridge: Cambridge University Press.

1984. "Ideological Continuities in Prehistoric Southern Africa: The Evidence of

Rock Art." Past and Present in Hunter-Gatherer Studies. Ed. C. Schrire. New York:

Academic Press. 225-252.

1985. "The San Artistic Achievement." African Arts 18(3): 54-59.

1986. "The Last Testament of the Southern San." South African Archaeological Bulletin 41: 10-11. 
1987a. "Beyond Style and Portrait: A Comparison of Tanzanian and Southern African Rock Art." Contemporary Studies on Khoisan, Part 2 (Quellen zur Khoisan-Forschung

5.2). Eds. R. Vossen, and K. Keuthmann. Hamburg: Helmut Buske Verlag. 93-139. . 1987b. "Paintings and Power: Ethnography and Rock Art in Southern Africa." The Past and Future of !Kung Ethnography: Critical Reflections and Symbolic Perspectives. Eds.

M. Biesele, R. Gordon, and R. Lee. Hamburg: Helmut Buske Verlag. 231-253. . 1988a. Reality and Non-Reality in San Rock Art. 25th Raymond Dart Lecture. Johannesburg: Witwatersrand University Press. . 1988b. The World of Man and the World of Spirit: An Interpretation of the Linton Rock Paintings. Margaret Shaw Lecture 2. Cape Town: South African Museum. . 1992. "Ethnographic Evidence Relating to 'Trancing' and 'Shamans' among Northern Bushmen." South African Archaeological Bulletin 47: 56-60.

1995. "Seeing and Construing: The Making and 'Meaning' of a Southern African

Rock Art Motif." Cambridge Archaeological Journal 5(1): 3-23.

. 1997a. "Agency, Art, and Altered Consciousness: A Motif in French (Quercy) Upper Palaeolithic Parietal Art." Antiquity 71(274): 810-830.

. 1997b. "Harnessing the Brain: Vision and Shamanism in Upper Palaeolithic Western Europe." Beyond Art: Pleistocene Image and Symbol. Eds. M.W. Conkey, O. Soffer, D. Stratmann, and N.G. Jablonski. Berkeley: University of California Press. 321-342.

. 2000a. Discovering Southern African Rock Art. Cape Town and Johannesburg: David Philip. . 2000b. Stories the Float from Afar: Ancestral Folklore of the San of Southern Africa. Cape Town: David Philip. . 2001a. "Brainstorming Images: Neuropsychology and Rock Art Research." Handbook of Rock Art Research. Ed. D. Whitley. Walnut Creek: AltaMira Press. 332-357. 2001b. "Monolithism and Polysemy: Scylla and Charybdis in Rock Art Research."

Theoretical Perspectives in Rock Art Research. Ed. K. Helskog. Oslo: Novus forlag. 23-39. 2002. The Mind in the Cave: Consciousness and the Origins of Art. London: Thames and Hudson.

. 2003. Images of Mystery: Rock Art of the Drakensberg. Paris: Éditions du Seuil.

. 2006. "Debating Rock Art: Myth and Ritual, Theories and Facts." South African Archaeological Bulletin 61: 105-114.

Lewis-Williams, James David, and Sam Challis. 2011. Deciphering Ancient Minds: The Mystery of San Bushmen Rock Art. London: Thames and Hudson.

Lewis-Williams, James David, and Thomas A. Dowson. 1988. “The Signs of All Times.

Entoptic Phenomena in Upper Paleolithic Art." Current Anthropology 29(2): 201-245. 1989. Images of Power. Understanding Bushman Rock Art. Johannesburg: Southern Book Publishers.

1990. "Through the Veil: San Rock Paintings and the Rock Face." South African Archaeological Bulletin 45: 5-16.

Lewis-Williams, James David, and Johannes H.N. Loubser. 1986. “Deceptive Appearances: A Critique of Southern African Rock Art Studies." Advances in World Archaeology 5: 251-289.

Lewis-Williams, James David, Geoffrey Blundell, Sam Challis, and Jamie Hampson. 2000. "Threads of Light: Re-examining a Motif in Southern African San Rock Art." South African Archaeological Bulletin 55: 123-136. 
McGranaghan, Mark, Sam Challis, and James David Lewis-Williams. 2013. “Joseph Millerd Orpen's 'A Glimpse into the Mythology of the Maluti Bushmen': A Contextual Introduction and Republished Text." Southern African Humanities 25: 137-66.

Mguni, Siyakha. 2012. "Five Years of Southern African Rock Art Research." Rock Art Studies. News of the World IV. Eds. P. Bahn, N. Franklin, and M. Strecker. Oxford: Oxbow Books. 99-112.

Morris, David. 2010. "Snake and Veil: The Rock Engravings of Driekopseiland, Northern Cape, South Africa." Seeing and Knowing: Rock Art With and Without Ethnography. Eds.

G. Blundell, C. Chippindale, and B. Smith. Walnut Creek: Left Coast Press. 37-53. 2014. "Wildebeest Kuil Rock Art Centre, South Africa: Controversy and Renown, Successes, and Shortcomings." Public Archaeology 13(1-3): 187-199.

Orpen, Joseph Millerd. 1874. "A Glimpse into the Mythology of the Maluti Bushmen." Cape Monthly Magazine 9(49): 1-13.

Rozwadowski, Andrzej. 2001a. "From Semiotics to Phenomenology: Central Asian Petroglyphs and the Indo-Iranian Mythology." Theoretical Perspectives in Rock Art Research. Ed. K. Helskog. Oslo: Novus Press. 155-174.

2001b. "The Petroglyphs of Central Asian from the Viewpoint of the Indo-Iranian Hypothesis." Indo-European Studies Bulletin 9(2): 9-19.

2001c. "Sun Gods or Shamans? Interpreting the 'Solar-Headed' Petroglyphs of Central Asia." The Archaeology of Shamanism. Ed. N. Price. London and New York: Routledge. 65-86.

2002a. "Crossing the Crack: Flying to the Cloud. Indo-Iranians, Shamanism and Central Asian Rock Art." Bolletino del Centro Camuno di Studi Preistorici 33: 97-105. 2002b. "Disappearing in the Cliffs: Shamanistic Aspects of Indo-Iranian Mythology as a Context for Interpreting Central Asian Petroglyphs." Spirits and Stones: Shamanism and Rock Art in Central Asia and Siberia. Eds. A. Rozwadowski, and M.M. Kośko. Poznań: Instytut Wschodni UAM. 49-79.

2003. Indoirańczycy - sztuka i mitologia. Petroglify Azji Środkowej. Poznań: Wydawnictwo Naukowe UAM.

2004. Symbols through Time: Interpreting the Rock Art of Central Asia. Poznań: Institute of Eastern Studies, Adam Mickiewicz University.

2009. Obrazy z przeszłości. Hermeneutyka sztuki naskalnej. Poznań: Wydawnictwo Naukowe UAM.

2012a. "Shamanism in Indigenous Context: Interpreting the Rock Art in Siberia." A Companion to Rock Art. Eds. J. McDonald, and P. Veth. Chichester: John Wiley \& Sons. 455-471.

2012b. "Shamanism, Rock Art and History: Implications from a Central Asian Case Study." Working with Rock Art: Recording, Presenting and Understanding Rock Art Using Indigenous Knowledge. Eds. B.W. Smith, K. Helskog, and D. Morris. Johannesburg: Wits University Press. 192-204.

2015. "Historic and Proto-Historic Shamanic Rock Art in Siberia: A View from the Altai." Quaderns de Prehistòria i Arqueologia de Castelló 33: 189-198.

2017a. Rock, Cracks and Drums: In Search of Ancient Shamanism in Siberia and Central Asia. Budapest: Molnar and Kelemen Oriental Publishers.

2017b. "Travelling through the Rock to the Otherworld: The Shamanic 'Grammar of Mind' within the Rock Art of Siberia." Cambridge Archaeological Journal. Online: <https://doi.org/10.1017/S095977431700004X>. 
Smith, Benjamin W. 2006. "Reading Rock Art and Writing Genetic History: Regionalism, Ethnicity and the Rock Art of Southern Africa." The Prehistory of Africa: Tracing the Linage of Modern Man. Ed. H. Soodyall. Johannesburg and Cape Town: Jonathan Ball Publishers. 76-96.

. 2013. "Rock Art Research in Africa." The Oxford Handbook of African Archaeology. Eds. P. Mitchell, and P. Lane. Oxford: Oxford University Press. 145-161.

Smith, Benjamin, and Melanie Duval. 2012. "Préservation et développement touristique des sites d'art rupestre de l'uKhahlamba-Drakensberg, Afrique du Sud: enjeux, obstacles et incidences sur le vivre-ensemble." Academics Papers: International Conference on 'Living with World Heritage in Africa.' Eds. C. Kpadonou, D. Neuba, H. Boko-Koudakossi, I. Odiaua, M.W. Mapesa, P. Abungu, S. Van Damme, and Y. Diedhiou. Pretoria: African World Heritage Fund (AWHF) and Department of Arts and Culture, South Africa. 188-199.

Smith, Benjamin W., and Sven Ouzman. 2004. "Taking Stock: Identifying Khoekhoen Herder Rock Art in Southern Africa." Current Anthropology 45(4): 499-527.

Smith, Benjamin, James David Lewis-Williams, Geoffrey Blundell, and Christopher Chippindale. 2000. "Archaeology and Symbolism in the New South African Coat of Arms." Antiquity 74: 467-468.

Ucko, Peter J., and Andree Rosenfeld. 1967. Paleolithic Cave Art. London: McGraw Hill. Vinnicombe, Patricia. 1967. "Rock-Painting Analysis." South African Archaeological Bulletin 88: 129-141.

1976. People of the Eland: Rock Paintings of the Drakensberg Bushmen as a Reflection of their Life and Thought. Pietermaritzburg: University of Natal Press. 